COMPLETE

ENGINEERING CHANGE NOTICE

Page 1 of $\geq$

\begin{tabular}{|c|c|c|c|c|c|c|}
\hline \multirow{3}{*}{$\begin{array}{l}\text { 2. ECN Category } \\
\text { (mark one) } \\
\text { Supplemental } \\
\text { Direct Revision } \\
\text { Change ECN } \\
\text { Temporary } \\
\text { Standby } \\
\text { Supersedure } \\
\text { Cancel Noid }\end{array}$} & \multirow{3}{*}{$\begin{array}{r}{[]} \\
{[\times]} \\
{[]} \\
{[]} \\
{[]} \\
{[]} \\
{[]}\end{array}$} & \multicolumn{2}{|c|}{$\begin{array}{l}\text { 3. Originator's Name, organization, MSIN, } \\
\text { and Telephone No. } \\
\text { B. Gneiting, SE Risk Management } \\
\text { and Model] ing, } \mathrm{H} 6-33,372-1663\end{array}$} & \multicolumn{2}{|c|}{$\begin{array}{l}\text { 3a. USQ Required? } \\
{[] \text { Yes }[X] \text { No }}\end{array}$} & $\begin{array}{l}\text { 4. Date } \\
05 / 01 / 96\end{array}$ \\
\hline & & \multicolumn{2}{|c|}{$\begin{array}{l}\text { 5. Project Title/No./Work Order No. } \\
\text { WHC-SD-WM-TP-431, ReV. } 1\end{array}$} & \multicolumn{2}{|c|}{$\begin{array}{l}\text { 6. Btdg./Sys./Fac. No. } \\
N / A\end{array}$} & $\begin{array}{l}\text { 7. Approval Designator } \\
\text { N/A }\end{array}$ \\
\hline & & \multicolumn{2}{|c|}{$\begin{array}{l}\text { 8. Document Numbers Changed by this ECN } \\
\text { (includes sheet no. and rev.) } \\
\text { WHC-SD-WM-TP-431, Rev. } 0\end{array}$} & \multicolumn{2}{|c|}{ 9. Related ECN No(s). } & 10. Related PO No. \\
\hline \multirow{2}{*}{\multicolumn{2}{|c|}{$\begin{array}{l}\text { 11a. Modification Work } \\
\text { [] Yes (fill out Blk. } \\
11 \mathrm{~b} \text { ) } \\
\text { [X] No (NA Blks. 11b, } \\
11 c, 11 \mathrm{~d} \text { ) }\end{array}$}} & \multirow[t]{2}{*}{$\begin{array}{l}\text { 11b. Work Package } \\
\text { No. } \\
\text { N/A }\end{array}$} & \multicolumn{2}{|c|}{$\begin{array}{l}\text { 11c. Modification Work Complete } \\
\text { N/A }\end{array}$} & \multicolumn{2}{|c|}{$\begin{array}{l}\text { 11d. Restored to Original Condi- } \\
\text { tion (Temp. or Standby ECN only) } \\
\text { N/A }\end{array}$} \\
\hline & & & \multicolumn{2}{|c|}{ Cog. Engineer Signature \& Date } & \multicolumn{2}{|c|}{ Cog. Engineer Signature \& Date } \\
\hline
\end{tabular}

12. Description of Change

This document contains the actual test information for the conversion of RDD-100

Version 3.0.2 to Version 4.0.3.

13a. Justification (mark one)

Criteria Change [] Design Improvement [] Environmental

As-Found

[X]

Facilitate Const

Const. Error/Omission

Facility Deactivation Design Error/Omission

13b. Justification Details

Document has newly inserted test results.

14. Distribution (include name, MSIN, and no. of copies)

N. G. Awadalla H6-33

C. N. Krohn H6-33

P. A. Baynes

H6-33

T. L. Moore

H6-33

K. E. Carpenter H6-33

S. P. Otte H6-33

B. C. Gneiting $\mathrm{H} 6-33$

L. G. Peck H6-33

M. E. Johnston H6-33

D. F. Salsman H6-33

Central. Files A3-88

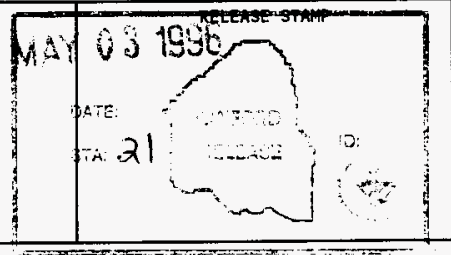

A-7900-013-2 (11/94) GEF095 


\section{ENGINEERING CHANGE NOTICE}

\begin{tabular}{|c|c|c|c|c|c|}
\hline \multirow{3}{*}{$\begin{array}{l}\text { 15. Design } \\
\text { Verification } \\
\text { Required } \\
\text { [] Yes } \\
\text { [] No }\end{array}$} & \multicolumn{4}{|c|}{$\begin{array}{l}\text { 16. Cost Impact } \\
\text { ENGINEERING }\end{array}$} & 17. Schedule Impact \\
\hline & Additional & $\$$ & Additional & $\$$ & Improvement \\
\hline & Savings & $\$$ & Savings & $\$$ & Delay \\
\hline
\end{tabular}

18. Change Impact Review: Indicate the related docunents (other than the engineering documents ident ified on side 1 ) that will be affected by the change described in Block 12. Enter the affected document number in Block 19. SDD/DD

Functional Design Criteria

[] Soismic/Stross Analysis

Operating Specification

[]

Stress/Design Report

Criticality Specification

[] Interface Control Drawing

Conceptual Design foport

[]

Equipment Spec

[]

Const. Spec.

Procurement Spec.

Vondor Information

OM Manual

[]

Calibration Procedure

Installation Procedure

Maintenance Procedure

[]

[]

[]

FSAR/SAR

Safoty Equipment List

Radiation Work Permit

Environmental lmpact Statement

[]

[]

[]

[]

Environmental Report

[]

Environmental Pormit

[]

[]

[]
[]
[]
[]
[]
[]
[]
[]
[]
[]
[]
[]
[]
[]
[]
[]

Tank Calibration Manual

Health Physice Procedure

Spares Multiple Unit Listing

Tost Procedures/Specification

Component Index

ASME Coded Item

Engineering Procedure

Operating Instruction

Operating Procedure

Operational Safety Requirement

IEFD Drawing

Cell Arrangement Drawing

Essential Material Specification

Fac. Proc. Samp. Schodulo

Human Factor Consideration

Computer Software

Electric Circuit Schedule

ICRS Procedure

Process Control Manual/Plan

Process Flow Chart

Purchase Requisition

Tickler File

fnepection Plan

Invontory Adjustment Roquest

19. Other Affected Documents: (NOTE: Documents listed below will not be revised by this ECN.) Signatures below indicate that the signing organization has been notified of other affected doctments listed below. Document Number/Revision

Document Number/Revision

Document Number Revision

$N / A$

20. Approvals

\section{Signature}

OPERATIONS AND ENGINEERING

Cog. Eng. B. C. Gneiting

Cog. Mgr. N. G. Awadalla

QA

Safety

Environ.

other
Date

D.C. etnating
N.G. Ousdalle
Signature

ARCHITECT -ENGINEER

PE

QA

Safety

Design

Environ.

other

\section{DEPARTMENT OF EMERGY}

signature or a Control Numer that

tracks the Approval signature

ADDIIIONAL
Date

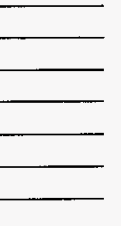

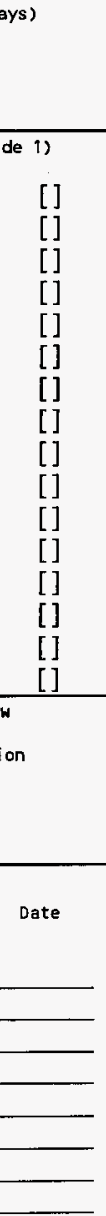




\title{
Test Documentation for Converting TWRS Baseline Data from RDD-100 V3.0.2.2 to V4.0.3
}

\author{
B. C. Gneiting \\ M. E. Johnston (TRW) \\ Westinghouse Hanford Company, Richland, WA 99352 \\ U.S. Department of Energy Contract DE-AC06-87RL10930 \\ EDT/ECN: 623906 \\ UC: 905 \\ Org Code: 74450 \\ Charge Code: D1M24 \\ B\&R Code: EW3120075 \\ Total Pages: 50
}

Key Words: RDD-100, Test P1an, requirements management, database.

Abstract: This document describes the test documentation required for converting between two versions of the RDD-100 software application, specifically version 3.0.2.2 and version 4.0.3. The area of focus in the successful conversion of the master data set between two versions of the database tool and their corresponding data structures.

TRADEMARK DISCLAIMER. Reference herein to any specific comercial product, process, or service by trade name, trademark, manufacturer, or otherwise, does not necessarily constitute or imply its endorsement, recommendation, or favoring by the United States Government or any agency thereof or its contractors or subcontractors.

Printed in the United States of America. To obtain copies of this document, contact: WHC/BCS Document Control Services, P.O. Box 1970, Mailstop H6-08, Richland HA 99352, Phone (509) 372-2420; Fax (509) 376-4989.
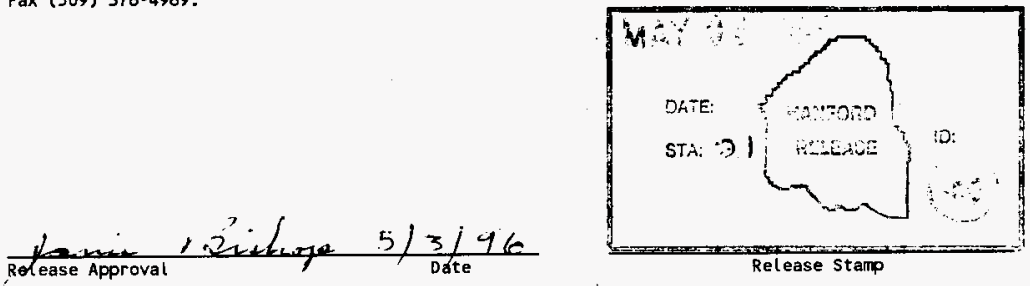

\section{Approved for Public Release}




\section{RECORD OF REVISION}

(1) Document Number

WHC-SD-WM-TP-431

Page 1

Rev. 1

(2) Title

Test Documentation for Converting TWRS Baseline Data From RDD-100 V3.02.2 to V4.0.3

CHAMGE CONTROL RECORD

\begin{tabular}{|c|c|c|c|}
\hline \multirow{2}{*}{ (3) Revision } & \multirow{2}{*}{ (4) Description of Change - Replace, Add, and Delete Pages } & \multicolumn{2}{|c|}{ Authorized for Release } \\
\hline & & (5) Cog. Engr. & (6) Cog. Mgr. \\
\hline 1 FS & $\begin{array}{l}\text { (7) Replace WHC-SD-WM-TP-431 Rev. } 0 \text { with } \\
\text { WHC-SD-WM-TP-43I Rev. } 1 \text { ECA- } E \text { Z37CA }\end{array}$ & $\begin{array}{l}\text { 8. E. expoting } \\
5 / 2 / 46\end{array}$ & $\begin{array}{l}\text { NG. Qurabalen } \\
5 / 2 / 96\end{array}$ \\
\hline & & & \\
\hline & & & \\
\hline & & & \\
\hline & & & \\
\hline & & & \\
\hline & & & \\
\hline & & & \\
\hline & & & \\
\hline & & & \\
\hline & & & \\
\hline & & & \\
\hline & & & \\
\hline & & & \\
\hline & & & \\
\hline & & & \\
\hline & & & \\
\hline & & & \\
\hline & & & \\
\hline & & & \\
\hline & & & \\
\hline & & & \\
\hline & & & \\
\hline & & & \\
\hline & & & \\
\hline & & & \\
\hline & & & \\
\hline & & & \\
\hline & & & \\
\hline & & & \\
\hline & & & \\
\hline & & & \\
\hline & & & \\
\hline
\end{tabular}




\section{TABLE OF CONTENTS}

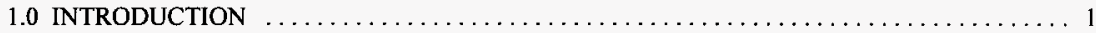

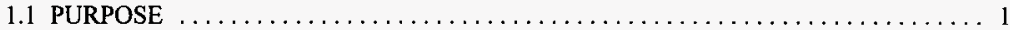

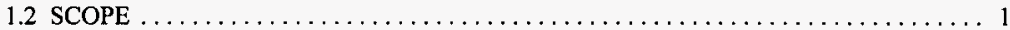

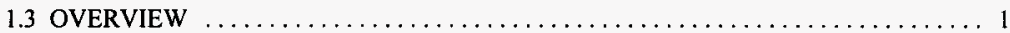

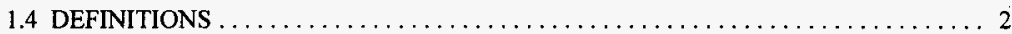

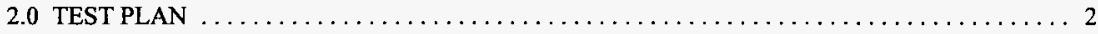

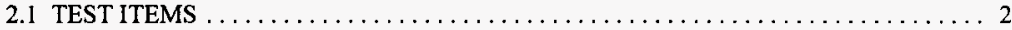

2.2 FEATURES TO BE TESTED/NOT TO BE TESTED $\ldots \ldots \ldots \ldots \ldots \ldots \ldots \ldots \ldots \ldots 2$

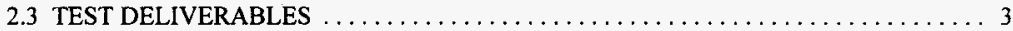

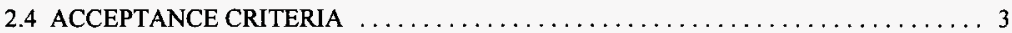

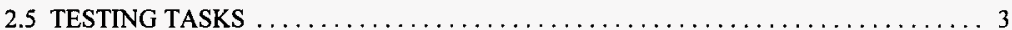

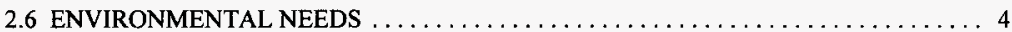

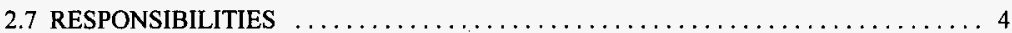

2.8 STAFFING AND TRAINING NEEDS $\ldots \ldots \ldots \ldots \ldots \ldots \ldots \ldots \ldots \ldots \ldots \ldots \ldots \ldots$

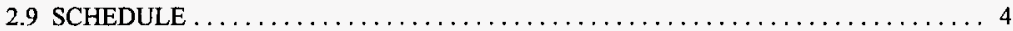

2.10 RISKS AND CONTINGENCIES $\ldots \ldots \ldots \ldots \ldots \ldots \ldots \ldots \ldots \ldots \ldots \ldots \ldots$

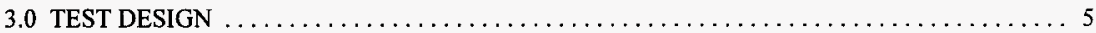

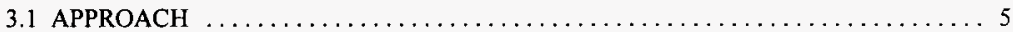

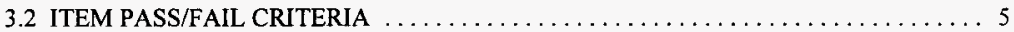

3.3 SUSPENSION CRITERIA AND RESUMPTION REQUIREMENTS $\ldots \ldots \ldots \ldots \ldots 5$

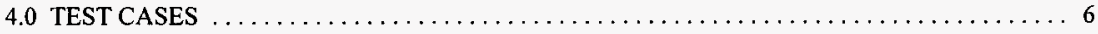

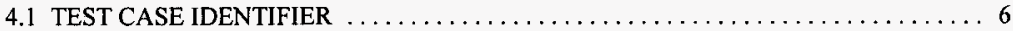

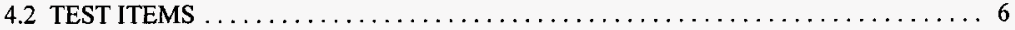

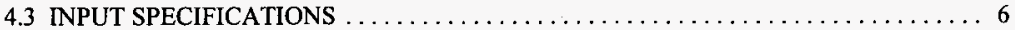

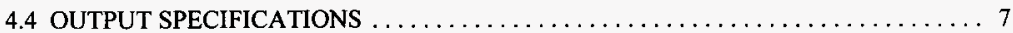



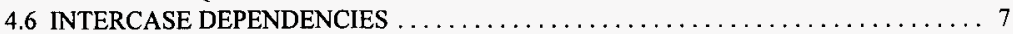

5.0 TEST PROCEDURES $\ldots \ldots \ldots \ldots \ldots \ldots \ldots \ldots \ldots \ldots \ldots \ldots \ldots \ldots \ldots \ldots \ldots \ldots \ldots$

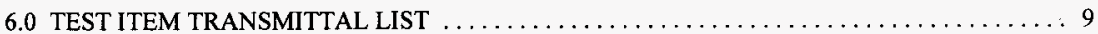

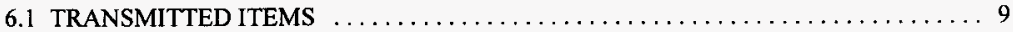

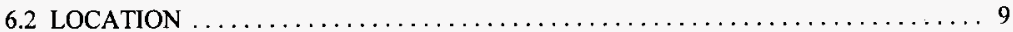



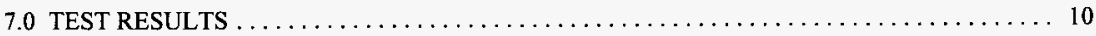

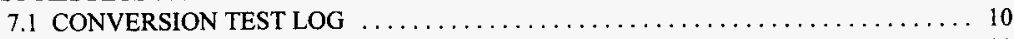

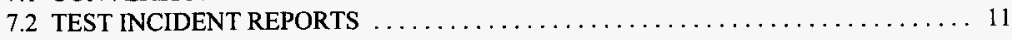

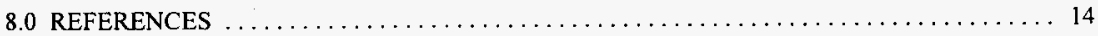

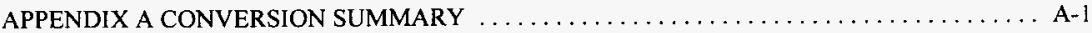

APPENDIX B DATABASE PROFILES $\ldots \ldots \ldots \ldots \ldots \ldots \ldots \ldots \ldots \ldots \ldots \ldots \ldots \ldots \ldots \ldots \ldots$

APPENDIX C DATABASE CONTENT DIFFERENCES $\ldots \ldots \ldots \ldots \ldots \ldots \ldots \ldots \ldots \ldots \ldots \ldots$ C-1 
WHC-SD-WM-TP-431 Riev. 1

\section{LIST OF FIGURES}

1 Test Incident Report for Test Case 1

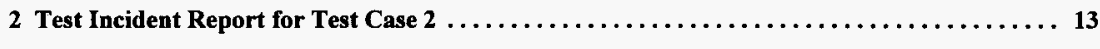

\section{LIST OF TABLES}

1. Conversion to RDD-100 Version 4.0.3 Test Log 10 


\subsection{INTRODUCTION}

\subsection{PURPOSE}

A formal systems engineering approach has been adopted at Hanford for the development of major systems like the Tank Waste Remediation System (TWRS). This includes performing the activities of mission analysis, functional analysis, requirements analysis, parametric analysis, and alternative analysis. To manage complex sets of requirements, provide document traceability, and support a broad range of related systems engineering activities, a tool known within Westinghouse Hanford Company (WHC) as the Requirements Management and Assured Compliance System (RMACS) is used. The main software tool in the RMACS system is the RDD-100 software tool set developed by Ascent Logic Corporation (ALC). This tool set contains the systems engineering data describing the TWRS technical baseline. This document provides the test documentation required for the conversion between two versions of the RDD-100 software application, from Version 3.0.2.2 to Version 4.0.3. The testing performed specifically addresses the conversion of the data set between the two versions. The purpose of the test documentation is to verify that the data in the database has come through the conversion without becoming corrupted.

\subsection{SCOPE}

The testing is intended to confirm that the data converted and then stored in Version 4.0 .3 of RDD-100 is identical to the data contained in Version 3.0.2.2. The RDD-100 application is a commercial off-the-shelf software package that has been in use at Hanford for about 3 years. The new version (4.0.3) has been extensively tested by the developer, been in use at Hanford for about 4 months, and has been in use by other companies. Only representative testing of the applications input and output capabilities will be performed to make sure it continues to function as expected. Reports previously developed with the older version (3.0.2.2) of the RDD-100 report writer will not be included in the formal conversion testing because they are always changing and are only used to create specific views of the data to be printed in a report format. Also, any RDD-100 generated reports used to define a technical baseline are independently reviewed for correctness. The extension of the schema to conform with the built-in Design Guide A schema will also not be addressed, as none of the data currently in the database will be affected.

\subsection{OVERVIEW}

The U.S. Department of Energy (DOE) established the TWRS Program to safely manage and dispose of the tank waste stored at the Hanford Site. The scope of the TWRS Program and projects is to receive, safely store, maintain, treat, and dispose of tank waste. Tank waste includes the current contents of 149 Single-Shell Tanks (SSTs), 28 Double-Shell Tanks (DSTs), 47 miscellaneous tanks, new waste that may be added to these facilities, and all encapsulated cesium and strontium stored onsite and returned from offsite users.

The TWRS Program has adopted a systems engineering approach to integrate all activities necessary to build a system that achieves the tank waste remediation mission. The infrastructure framework being developed to enable effective deployment of systems engineering includes a set of computer-based tools to automate the process and manage information. The RMACS is one of the systems of computer-based tools being used to assist the TWRS management and engineers in the 
application of the systems engineering process to the TWRS domain. This system assists the systems engineer in evaluating, analyzing, grouping, connecting, categorizing, storing, and communicating information and data that relate to the tank waste system. As mentioned above, the RDD-100 software application is the main component of RMACS.

Currently TWRS is using RDD-100 Version 3.0.2.2, which is out of date and no longer supported by ALC. Therefore, technical support, consulting, and training services will no longer be available from the vendor. To effectively utilize the investment in RDD-100, upgrading to the current version of $\mathrm{RDD}$, Version 4.0 .3 , is necessary. The original requirements that led to selecting RDD-100 to support the systems engineering activity and store the technical baseline for TWRS have not changed and are still satisfied by Version 4.0.3. In this version, ALC provides the user with three main templates or schema that have built-in tools or utilities. It was decided to take advantage of the built-in support features and use the Design Guide A schema, which appears to be the best fit for TWRS current and future plans. The product of the conversion activity is to successfully take the current TWRS technical baseline data stored in Version 3.0.2.2 and move it over to Version 4.0.3 without losing any data element definitions or relationships between the elements.

\subsection{DEFINITIONS}

$\begin{array}{ll}\text { ALC } \quad- & \text { Ascent Logic Corporation } \\ \text { DOE - } & \text { U.S. Department of Energy } \\ \text { DST }- & \text { Double-Shell Tank } \\ \text { HSTB - } & \text { Hanford Site Technical Baseline } \\ \text { RDD - } & \text { RDD-100/Requirements Driven Development } \\ \text { SST - } & \text { Single-Shell Tank } \\ \text { TWRS - } & \text { Tank Waste Remediation System }\end{array}$

\subsection{TEST PLAN}

\subsection{TEST ITEMS}

The TWRS systems engineering data contained in the RDD-100 database, in the form of Elements, Relations, and Attributes, will be tested to confirm the completeness and accuracy after the data is transferred to the new software version.

\subsection{FEATURES TO BE TESTED/NOT TO BE TESTED}

\section{Conversion Data:}

After the data stored in the RDD-100 database is transferred from Version 3.0.2.2 to Version 4.0.3, it will be checked manually to ensure that the new version contains the proper numbers of elements of each type, along with their relationships and attributes. The data will also be sampled to compare the two data sets and verify that there are no differences. 


\section{RDD-100:}

The RDD-100 Version 4.0.3 software application is a commercial product that was released about a year ago and has been used exclusively by other companies. The product has been thoroughly tested and no further testing is required for this task. However, some representative testing of the software's input and output functions will be performed and reviewed as a result of the data conversion testing. The updated version of RDD provides additional capability, typical of an software upgrade release, that can be utilized by the TWRS Program.

\subsection{TEST DELIVERABLES}

The test documentation will be contained in one document that defines the test plan, design, procedures, and results. The test results will include the following topics:

Test Logs

Test Incident Reports

Test Summary Reports

Test Output data

\subsection{ACCEPTANCE CRITERIA}

The individual pass/fail criteria described in Section 3.2 must all be satisfied in order for the conversion as a whole to be accepted.

\subsection{TESTING TASKS}

\section{Side-by-Side Execution:}

A set of updates to the RDD-100 data will be prepared for both versions.

Identical changes will be made to the data stored in both versions using the standard input interface.

The results will be compared manually based on the data collected automatically by the RDD-100 generated reports described below.

\section{Data Count:}

A profiling report for Version 3.0.2.2 that will produce an output to match the output from the Database Profile report provided by Version 4.0 .3 has been written and checked.

Profiles will be produced for the data sets stored in each version.

The profiles will be compared manually to make sure the number counts for each element and associated relationships are the same. 


\section{Detailed Sampling:}

A database sampling report that will produce detailed output for a selected number (representative sample) of data items has been written for both versions of RDD-100.

The report will be run on both sets of data.

The output will be compared using the UNIX 'diff' utility, which will output a file of the differences between the two data sets.

\subsection{ENVIRONMENTAL NEEDS}

The new version of the RDD-100 application has already been installed on a UNIX Sun server with the capability of checking out a license. At least one UNIX Sun station that runs the Solaris 1.1 operating system is required to run the RDD-100 application and produce the reports. The UNIX station needs access to the Sun server over the Hanford Local Area Network (HLAN) to check out a license and to share data with other Sun stations on the network. There are no special security requirements.

\subsection{RESPONSIBILITIES}

Members of the TWRS Technical Integration team and subcontractors are responsible for all areas of the testing.

\subsection{STAFFING AND TRAINING NEEDS}

One project leader, in charge of the testing acceptance, timing, and task priorities.

One RDD-100 programmer, to generate the database profile report for Version 3.0.2.2 and to be available if changes need to be made to reports so they produce acceptable output.

Two test technicians, to perform the tests and track progress on individual tests.

All of these resources are available within the current RDD-100 user group, which includes an ALC consultant.

\subsection{SCHEDULE}

The actual testing will take between one and four days, depending on the number and difficulty of the problems found with the converted data. It is expected, from preliminary tests that the difficulties will be few, minor, and easily resolved. 


\subsection{RISKS AND CONTINGENCIES}

It is assumed that all of the data stored in RDD-100 Version 3.0.2.2 will be converted to Version 4.0.3 without major difficulty. If difficulties are encountered, it is possible that the conversion effort will require a revision of the data storage structure, data, or some other modification. If this occurs, the current RDD-100 Version 3.0.2.2 may still be used until the difficulties are resolved.

\subsection{TEST DESIGN}

\subsection{APPROACH}

The data stored in RDD- 100 will be tested by running a database profile report for the data in both RDD versions. The profile report will contain counts of instances for each element type and their relationships.

For all element types populated:

Number of instances.

Number of times each attribute is populated.

For all relationships populated:

Number of times each relationship is populated.

Number of times each target of the relationship is used.

The data will also be tested by running a database sampler report on both sets of data. The output from the reports should be in the same format and allow for the data to be sampled as often as desired. At this time, the output interval is every element's name, number, and description. The interval can be easily changed if needed. Then the output for the two sets will be compared using the UNIX "diff" utility.

A third test will round out the set by checking the input features, which are expected to function properly because they have been thoroughly tested by the vendor and other users. Changes will be made through the normal input function to identical data sets in both versions. The reports should yield results similar to those obtained for the first and second test case.

\subsection{ITEM PASS/FAIL CRITERIA}

The data transfer between versions will pass the test if the profile reports' output show that the two versions have identical profiles and the database sample reports have no differences as identified by the UNIX "diff" utility.

\subsection{SUSPENSION CRITERIA AND RESUMPTION REQUIREMENTS}

If the data stored in Version 4.0.3 of RDD is found to be different from that stored in the current version, the data testing will stop and will not resume until the reason for the difference is found. If necessary, a work-around path will be defined and testing resurned. 


\subsection{TEST CASES}

The test case format shall consist of a test case identifier, an explanation of the items being tested, input and output specifications, environmental needs, anid any special requirements specific to that test case.

\subsection{TEST CASE IDENTIFIER}

The test cases will be identified by a short description of the testing that is to be performed. Only three test cases are considered necessary at this time: Database Statistics, Database Content, and Database Activity.

\subsection{TEST ITEMS}

\section{Database Statistics:}

This test case will compare the number of instances of each data type for the same data set stored in each of the two versions of RDD-100. The count comparisons will be for: the number of instances of each element type, the number of targets for each relationship available to each element type, and the number of each attribute available for each element type.

\section{Database Content:}

This test case will compare selected instances of the elements to make sure they are in the same order in each version of RDD-100 and that the names, numbers, and descriptions of the instances are identical.

\section{Database Activity:}

This test case will utilize the normal input features of RDD-100 to make changes to the data set in each version. Next a check will be made to make sure the data was changed and stored correctly in Version 4.0 .3 by comparing the database profile reports for the two versions. The changes made to the database supporting the most recent change request package will be made in the new version and a database profile report will be run the make the comparison. This test is performed to round out the test set and check that the input function performs as expected. Because the software has been thoroughly tested by ALC and other users throughout the country, the results of the test are expected to be positive.

\subsection{INPUT SPECIFICATIONS}

For the first two test cases, the entire RDD-100 data set will be checked without using the standard input features. A data set stored in Version 3.0.2.2 will be converted and stored in Version 4.0.3. The resulting data set will be checked to make sure the conversion was a success. For the Database Activity test case, the normal input functions will be used to make the changes requested in the most recent change request package. 


\subsection{OUTPUT SPECIFICATIONS}

\section{Database Statistics:}

The output will be in the form of a table that provides a profile of the data set and sums the number of instances. The format is shown in the Appendix B, DATABASE PROFILE. The tables output by the two versions of RDD-100 will be compared to determine whether or not the statistics match.

\section{Database Content:}

The output will be in the form of an ASCII text file that consists of groupings of Name, Number, and Description for every instance of every element type in the data set. The files output by the two versions of RDD- 100 will be compared by the UNIX "diff" utility to determine whether or not there are any differences.

\section{Database Activity:}

The output will be two Database Profile reports, which contain the changes to the data set that were requested by the most recent change request package. Data structure profiles will be created for both versions of RDD-100. These two reports will be compared to see if the results are the same. Also the reports created before entering the changes will be compared to make sure both sets of results are consistent.

\subsection{SPECIAL REQUIREMENTS}

\section{Database Statistics:}

No special requirements.

\section{Database Content:}

In RDD-100 Version 3.0.2.2, the names of all the instances for all the element types must be changed to all upper case letters. This is required to take into account a difference in the way alphabetizing is done in the two different versions of RDD-100. Because of this, the "diff" utility must be executed using the $-I$ option.

\section{Database Activity:}

No special requirements.

\subsection{INTERCASE DEPENDENCIES}

There are no true dependencies between the first two cases. It is recommended, however, that the Database Statistics test case be performed first, because if it fails, the Database Content test case is guaranteed to fail. There are no dependencies between the second and third cases. The first case must be passed before the third case will have any meaning. 


\subsection{TEST PROCEDURES}

\section{Database Statistics:}

1. Log: See Section 7.1, Test Log.

2. Setup: RDD-100 must be started in each version using the appropriate data set.

3. Start: N/A

4. Proceed: Print the Database Profile, (Appendix B) report in both versions of RDD-100 and compare the numbers to ensure that they match between the two data sets.

5. Measure: N/A

6. Shutdown: If it becomes necessary to suspend testing, there are no actions that are required to safely shut down.

7. Restart: Simply follow the Setup and Proceed procedures.

8. Stop: N/A

9. Contingencies: Any anomalous events will have to be evaluated before a response can be formulated. Anomalous events will be recorded on the test $\log$ and test incident reports (Section 7.2) will be generated to detail the event and its resolution.

\section{Database Content:}

1. Log: See attached Test Log.

2. Setup: RDD-100 must be started in each version using the appropriate data set.

3. Start: N/A

4. Proceed: Print the Database Sampler report in both versions of RDD-100 and compare the output using the UNIX "diff" utility.

5. Measure: N/A

6. Shutdown: If it becomes necessary to suspend testing, there are no actions that are required to safely shut down.

7. Restart: Simply follow the Setup and Proceed procedures.

8. Stop: N/A

9. Contingencies: Any anomalous events will have to be evaluated before a response can be formulated. Anomalous events will be recorded on the test $\log$ and test incident reports will be generated to detail the event and its resolution.

\section{Database Activity:}

1. Log: See attached Test Log.

2. Setup: RDD-100 must be started in each version using the appropriate data set.

3. Start: N/A

4. Proceed: Make changes to the data set stored in both versions of RDD-100 using the requested changes in the most recent change request package. Print the Database Profile report in both versions of RDD-100 and compare the numbers. The comparison results should be consistent with those obtained in the Database Statistics test case.

5. Measure: N/A

6. Shutdown: If it becomes necessary to suspend testing, there are no actions that are required to safely shut down.

7. Restart: Simply follow the Setup and Proceed procedures.

8. Stop: N/A 
9. Contingencies: Any anomalous events will have to be evaluated before a response can be formulated. Anomalous events will be recorded on the test log and test incident reports will be generated to detail the event and its resolution.

\subsection{TEST ITEM TRANSMITTAL LIST}

\subsection{TRANSMITTED ITEMS}

The TWRS technical baseline data used to produce the TWRS Functions and Requirements Document, WHC-SD-WM-FRD-020, Rev. 0, is stored in Version 3.0.2.2 of the RDD-100 system engineering software system. The master data set of the TWRS technical baseline, Revision 0 , is stored on a Sun SPARC Server named twrsse. The computer files containing this version of the technical baseline are detailed in the Supporting Document "Tank Waste Remediation Systems Technical Baseline Database," document number WHC-SD-WM-CSWD-079, Rev. 0. The master data set was converted to the new version of RDD- 100 (4.0.3) and tested.

Several pending changes to the Rev. 0 technical baseline have been made using the 3.0 .2 .2 version of RDD-100. These change files (RDD-100 delta files) were used in the "database activity" testing. The delta files were obtained from the TWRS RDD-100 System Administrator and converted to the Version 4.0 .3 format.

The list of files used in the testing, their full path, and the computer system they reside on are contained in the next section.

\subsection{LOCATION}

All items used in testing the new version of RDD-100 are files stored on Sun workstations. The Sun workstations containing the original files and the files used in test work area are designated by name as follows:

Sun SPARC Server 1000 - twrsse

Sun SPARC 10/41 - electro (Tester)

The master image file containing the technical baseline (Version 3.0.2.2):

twrsse:/export/rdd/cmb1/twrs/New/twrs/Rev0-030196.im.Z

The original RDD-100 Version 3.0.2.2 change files:

$\begin{array}{llll}\text { directory: } & \text { electro:/home/MEJ881/Conversion/DCRs } & \\ \text { files: } & \text { TWR215216.rdt } & \text { TWR96246.rdt } & \text { TWR96245.rdt } \\ & \text { TWR96217.rdt } & \text { TWR96233.rdt.302 } & \text { TWR96247.rdt } \\ & \text { TWR96230.rdt } & \text { TWR96236.rdt } & \text { TWR96248.rdt } \\ & \text { TWR96231.rdt.302 } & \text { TWR96242.rdt } & \text { W314002.rdt } \\ & \text { TWR96232.rdt } & \text { TWR96244.rdt } & \text { W314003.rdt } \\ & & & \text { W314004.rdt }\end{array}$

The Revision 0 technical baseline converted to Version 4.0.3: electro:/home/MEJ881/Conversion/Rev0-030196.403.im.Z 
The change files converted to Version 4.0.3:

directory: twrsse:/export/rdd/302to403/converted

files: $\quad$ same as above except the .302 is removed

\subsection{STATUS}

All of the items transmitted are configured as expected and do not result in any deviations to the test plan.

\subsection{TEST RESULT'S}

The test results are separated into four main pieces.

1) A summary of the testing performed to verify that the upgrade to a new version of RDD-100 was successful is contained in Appendix A.

2) The database profile tables showing element and relationship counts for four separate images are contained in Appendix B.

3) The report showing database content differences is contained in Appendix C.

4) The test log and incident reports are contained in the sections below.

\subsection{CONVERSION TEST LOG}

This section summarizes any test anomalies that are written up in a test incident report. The summary is contained in a test $\log$ (Table 1). A test witness was not consiclered necessary for this testing activity and, therefore, was left out of the test log.

Table 1. Conversion to RDD-100 Version 4.0.3 Test Log

\begin{tabular}{|l|l|l|l|}
\hline Test Case & Pass/Fail & Incident Number or Comment & Signature/Date: \\
\hline $\begin{array}{l}\text { Database } \\
\text { Statistics }\end{array}$ & Pass & $\begin{array}{l}\text { 1-Critical Issues attribute Issue Type } \\
\text { See Appendix B, } \\
\text { Database Profile image Rev0-030196 (p. B-2) } \\
\text { Database Profile image Rev0-040196-403 (p. B-9) }\end{array}$ & $\begin{array}{l}\text { Test Performer: } \\
\text { Mark Johnston }\end{array}$ \\
\hline $\begin{array}{l}\text { Database } \\
\text { Content }\end{array}$ & Pass & $\begin{array}{l}\text { 2-Degree symbol in text } \\
\text { See Appendix C }\end{array}$ & $\begin{array}{l}\text { Test Performer: } \\
\text { Mark Johnston }\end{array}$ \\
\hline $\begin{array}{l}3 \\
\text { Database } \\
\text { Activity }\end{array}$ & Pass & $\begin{array}{l}\text { See Appendix B, } \\
\text { Database Profile image TWRS-0308.v302 (p. B-16) } \\
\text { Database Profile image TWRS -030895-403 (p. B-23) }\end{array}$ & $\begin{array}{l}\text { Test Performer: } \\
\text { Mark Johnston }\end{array}$ \\
\hline
\end{tabular}


WHC-SD-WM-TP-431 Rev. 1

\subsection{TEST INCIDENT REPORTS}

This section contains the Test Incident Reports that are listed in the Test Log. Figure 1 shows the test incident report generated for test Case 1 - Database Statistics and Figure 2 shows the test incident report generated for test Case 2 - Database Content. 
Figure 1. Test Incident Report for Test Case 1.

TEST INCWENT REPORT

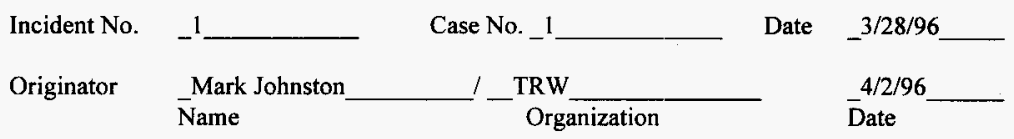

Description of Incident:

The Database Profile report shows that in v4.0.3, there are 23 more instances of the element type Critical Issue that have the value 'Issue' for the attribute Issue Type than there are in v3.0.2. This is because in v4.0.3, 'nil' (which was the value for those 23 in v3.0.2) is not a valid value for the Issue Type attribute.

[ ] Fix Before Implementation

[ ] Change in Scope
[ ] Fix After Implementation

[x] No Fix Required

Action Taken:

It was felt that no action was necessary since 'Issue' was the value which probably should have been assigned to the attribute for those elements.

Impact On Previous or Following Tests:

None

Prepared by:

Test Performer_Mark Johnston Name I TRW $04 / 02 / 96$

Organization Date


Figure 2. Test Incident Report for Test Case 2.

\section{TEST INCIDENT REPORT}

Incident No.

Case No. 2

Date $\quad 3 / 28 / 96$

Originator

$\overline{\text { Name }}^{\text {Mark Johnston }}$

I - TRW

Organization

Date

Description of Incident:

The UNIX diff utility showed that in three cases the description field of an element contained a degree symbol in version 3.0.2, which is not available in v4.0.3 and showed up as a control character.

[x] Fix Before Implementation

[ ] Fix After Implementation

[ ] Change in Scope

[ ] No Fix Required

Action Taken:

The control character was replaced with the word 'degrees' in all three cases.

Impact On Previous or Following Tests:

None

Prepared by:

Test Performer $\underset{\text { Name }}{\text { Mark Johnston } \_} \stackrel{\text { TRW }}{\text { Organization }}-\frac{\text { Date }}{04 / 02 / 96}$ 
WHC-SD-WM-TP-431 Rev. 1

\subsection{REFERENCES}

The following documents were used as sources of information for the test plan.

ANSI/IEEE 829-1983, Standard for Software Test Documentation, IEEE, 1983.

ANSI/IEEE 1008-1987, Standard for Software Unit Testing, IEEE, 1987.

Walker, Kevin G, Test Plan for the Integrated Dynamic Modeling and Management System (IDDMS), LATA, April 26, 1995.

WHC-CM-3-10, Software Practices, WHC, January 31, 1993 


\section{APPENDIX A}

\section{CONVERSION TEST SUMMARY}

\subsection{Summary}

The testing confirmed that conversion of the TWRS technical baseline data from Version 3.0.2.2 to Version 4.0.3 of RDD-100 was successful. None of the three test cases showed any major inconsistencies between the data in RDD-100 v3.0.2 and v4.0.3. The data was tested to be certain that the number of elements, relations and attributes of each type matched, that the name, number and description matched between the two versions, and to provide user confidence in the compatibility between the two versions. The testing was performed by Mark Johnston on a SUN'SPARC 10 computer over the course of several days. The data files can be found, along with the reports and output from the reports in the /export/rdd/302to403/Converted directory.

\subsection{Variances}

None

\subsection{Comprehensive Assessment}

The testing process was reasonably comprehensive, as it checks almost every aspect of the data transferred. Two aspects were not directly tested. First, some of the attributes were not tested to determine if they contain the correct data; however, the number of times the attributes were populated was checked. Secondly, only spot checks were made to determine if relationships were still associated with the correct elements. The extra effort of manually performing this check on all relationships was not considered necessary, since the count for each set of relationships and elements was correct and the conversion routines in RDD-100 v4.0.3 have had ample time to be thoroughly tested by the vendor and users.

\subsection{Summary of Results}

In the first test case, there were 23 Critical Issues whose Issue Type attribute was changed to 'Issue' from a value of nil. This is not a problem since all Critical Issues should have their Issue Type attribute populated, and the default value is Issue. In the second test case, there were minor differences between three descriptions of System Requirements in the two versions because of the degree symbol, which is not supported in v4.0.3. The third test case showed no differences.

\subsection{Evaluation}

Only a few very minor adjustments had to be made to the TWRS baseline data set to complete the conversion to RDD-100 Version 4.0.3. The test results show that the data conversion was a success and the new version of RDD-100 can be used to manage the TWRS technical baseline 


\subsection{Summary of Activities}

The major testing activities were writing and debugging the database query reports to be run on the data sets, running those queries, resolving incidlents and performing the documentation to support the conversion. The writing and debugging of the database query reports took approximately one week of a single person staffing and computer usage. Running the queries and resolving incidents took three days. Documenting the entire process took approximately one week. The total resource usage for the project was about three weeks of user and machine time, with the total time elapsed from start of the process to the end being four months because of vacations, holidays and other work intervening. 
WHC-SD-WM-TP-431 Rev. 1

APPENDIX B

DATABASE PROFIL.S

B-1 


\title{
DATABASE PROFILE
}

\author{
of \\ Facility: DOE \\ of the image \\ Rev0-030196
}

\section{April 1996 \\ 8:17:49 am}

\section{Prepared By:}

\section{TWRS Systems Engineering}


TABLE 1 DOE Relationships

\begin{tabular}{|c|c|c|c|}
\hline \multirow[t]{15}{*}{ SystemRequirement } & \multirow[t]{15}{*}{1460} & annotated by & Comment 1 \\
\hline & & categorized by & Category 1487 \\
\hline & & documented by & Source 1020 \\
\hline & & incorporated by & SystemRequirement 46 \\
\hline & & incorporates & SystemRequirement 46 \\
\hline & & primary is & Organization 141 \\
\hline & & traced from & Criticalissue 408 \\
\hline & & & Decision 281 \\
\hline & & traces to & Component 1028 \\
\hline & & & Criticallssue 1 \\
\hline & & & Decision 334 \\
\hline & & & RequiredAnalysis 1 \\
\hline & & & Source 5 \\
\hline & & & TimeFunction 3572 \\
\hline & & & TimeItem 2355 \\
\hline \multirow[t]{10}{*}{ TimeItem } & \multirow[t]{10}{*}{948} & annotated by & Comment 64 \\
\hline & & carried by & ItemLink 50 \\
\hline & & current decomposition & INet 182 \\
\hline & & input to & TimeFunction 917 \\
\hline & & output from & TimeFunction 963 \\
\hline & & primary is & Organization 150 \\
\hline & & refined by & INet 183 \\
\hline & & traced from & Criticalissue 99 \\
\hline & & & Decision 1 \\
\hline & & & SystemRequirement 2355 \\
\hline
\end{tabular}

B-3 
TABLE 1 DOE Relationships

\begin{tabular}{|c|c|c|c|}
\hline \multirow[t]{10}{*}{ Decision } & \multirow[t]{10}{*}{417} & analyzed by & RequiredAnalysis 53 \\
\hline & & categorized by & Category 42 \\
\hline & & documented ty & Source 151 \\
\hline & & primary is & Organization 55 \\
\hline & & traced from & Criticallssue 2 \\
\hline & & & SystemRequirement 334 \\
\hline & & traces to & Component 132 \\
\hline & & & Criticallssue 91 \\
\hline & & & SystemRequirement 281 \\
\hline & & & TimeItem 1 \\
\hline \multirow[t]{6}{*}{ Source } & \multirow[t]{6}{*}{388} & annotated by & Comment 213 \\
\hline & & categorized by & Category 1 \\
\hline & & documents & Decision 151 \\
\hline & & & RequiredAnalysis 6 \\
\hline & & & SystemRequirement 1020 \\
\hline & & traced from & SystemRequirement 5 \\
\hline \multirow[t]{9}{*}{ Criticallssue } & \multirow[t]{9}{*}{341} & analyzed by & RequiredAnalysis 275 \\
\hline & & primary is & Organization 95 \\
\hline & & secondary is & Organization 1 \\
\hline & & traced from & Criticallssue 1 \\
\hline & & & Decision 91 \\
\hline & & & SystemRequirement 1 \\
\hline & & \multirow[t]{3}{*}{ traces to } & Component 2 \\
\hline & & & Criticallssue 1 \\
\hline & & & Decision 2 \\
\hline
\end{tabular}

B-4 
TABLE 1 DOE Relationships

\begin{tabular}{|c|c|c|c|}
\hline & & & RequiredAnalysis 3 \\
\hline & & & SystemRequirement 408 \\
\hline & & & TimeFunction 7 \\
\hline & & & TimeItem 99 \\
\hline RequiredAnalysis & 333 & analyzes & Criticallssue 275 \\
\hline & & & Decision 53 \\
\hline & & documented by & Source 6 \\
\hline & & primary is & Organization 148 \\
\hline & & secondary is & Organization 6 \\
\hline & & traced from & Criticallssue 3 \\
\hline & & & SystemRequirement 1 \\
\hline Comment & 304 & annotates & ItemLink 80 \\
\hline & & & Source 213 \\
\hline & & & SystemRequirement 1 \\
\hline & & & TimeItem 64 \\
\hline & & categorized by & Category 4 \\
\hline TimeFunction & 190 & current decomposition & FNet 47 \\
\hline & & decomposed by & FNet 48 \\
\hline & & inputs & TimeItem 917 \\
\hline & & outputs & Timeltem 963 \\
\hline & & performed by & Component 77 \\
\hline & & & System 1 \\
\hline & & primary is & Organization 11 \\
\hline & & traced from & Criticallssue 7 \\
\hline & & & SystemRequirement 3572 \\
\hline
\end{tabular}

B-5 
Database Profile

TABLE 1 DOE Relationships

\begin{tabular}{|c|c|c|c|}
\hline \multirow[t]{6}{*}{ Component } & \multirow[t]{6}{*}{80} & built from & Component 79 \\
\hline & & built in & Component 79 \\
\hline & & performs & TimeFunction 77 \\
\hline & & \multirow[t]{3}{*}{ traced from } & CriticalIssue 2 \\
\hline & & & Decision 132 \\
\hline & & & SystemRequirement 1028 \\
\hline \multirow[t]{2}{*}{ ItemLink } & \multirow[t]{2}{*}{36} & annotated by & Comment 80 \\
\hline & & carries & TimeItem 50 \\
\hline \multirow[t]{8}{*}{ Organization } & \multirow[t]{8}{*}{28} & \multirow[t]{6}{*}{ primary for } & Criticallssue 95 \\
\hline & & & Decision 55 \\
\hline & & & RequiredAnalysis 148 \\
\hline & & & SystemRequirement 141 \\
\hline & & & TimeFunction 11 \\
\hline & & & TimeItem 150 \\
\hline & & \multirow[t]{2}{*}{ secondary for } & Criticallssue 1 \\
\hline & & & RequiredAnalysis 6 \\
\hline \multirow[t]{4}{*}{ Category } & \multirow[t]{4}{*}{8} & \multirow[t]{4}{*}{ categorizes } & Comment 4 \\
\hline & & & Decision 42 \\
\hline & & & Source 1 \\
\hline & & & SystemRequirement 1487 \\
\hline
\end{tabular}

B-6 
TABLE 2 DOE Attributes

\begin{tabular}{|c|c|c|c|}
\hline \multirow[t]{4}{*}{ SystemRequirement } & \multirow[t]{4}{*}{1460} & Description & 1379 \\
\hline & & Line Number & 1 \\
\hline & & Number & 1149 \\
\hline & & Paragraph Title & 64 \\
\hline \multirow[t]{5}{*}{ TimeItem } & \multirow[t]{5}{*}{948} & Size & 948 \\
\hline & & Description & 923 \\
\hline & & IDEF0 Type & input: 948 \\
\hline & & Number & 61 \\
\hline & & Message Priority & 948 \\
\hline \multirow[t]{7}{*}{ Decision } & \multirow[t]{7}{*}{417} & Alternatives & 74 \\
\hline & & Choice & 113 \\
\hline & & Description & 122 \\
\hline & & Number & 165 \\
\hline & & Problem & 4 \\
\hline & & \multirow[t]{2}{*}{ Status } & Enabling Assumption: 51 \\
\hline & & & Resolved: 113 \\
\hline \multirow[t]{8}{*}{ Source } & \multirow[t]{8}{*}{388} & Abbreviation & 1 \\
\hline & & Description & 286 \\
\hline & & Number & 50 \\
\hline & & \multirow[t]{5}{*}{ Source Type } & Meeting Minutes: 1 \\
\hline & & & $\begin{array}{l}\text { Originating Requirements: } \\
215\end{array}$ \\
\hline & & & Project Memo: 5 \\
\hline & & & Standard: 2 \\
\hline & & & Trade-off Study Report: 5 \\
\hline \multirow[t]{3}{*}{ Criticallssue } & \multirow[t]{3}{*}{341} & Actual Date & 35 \\
\hline & & Description & 338 \\
\hline & & Issue Type & Issue: 300 \\
\hline
\end{tabular}

B-7 
TABLE 2 DOE Attributes

\begin{tabular}{|c|c|c|c|}
\hline & & & Required Analysis: 18 \\
\hline & & Number & 137 \\
\hline & & Due Date & 114 \\
\hline \multirow[t]{2}{*}{ RequiredAnalysis } & \multirow[t]{2}{*}{333} & Description & 326 \\
\hline & & Number & 138 \\
\hline \multirow[t]{2}{*}{ Comment } & \multirow[t]{2}{*}{304} & Abbreviation & 83 \\
\hline & & Description & 304 \\
\hline \multirow[t]{4}{*}{ TimeFunction } & \multirow[t]{4}{*}{190} & Debugging Mode & none: 190 \\
\hline & & Description & 184 \\
\hline & & Execution Level & follow decomposition: 190 \\
\hline & & Number & 188 \\
\hline \multirow[t]{2}{*}{ Component } & \multirow[t]{2}{*}{80} & Description & 79 \\
\hline & & Number & 80 \\
\hline \multirow[t]{2}{*}{ ItemLink } & \multirow[t]{2}{*}{36} & Abbreviation & 26 \\
\hline & & Number & 36 \\
\hline Organization & 28 & & \\
\hline \multirow[t]{2}{*}{ Category } & \multirow[t]{2}{*}{8} & Description & 1 \\
\hline & & Number & 3 \\
\hline
\end{tabular}


WHC-SD-WM-TP-431 Rev. 1

\section{DATABASE PROFILE}

of

Facility: DOE

of the image

Rev0-040196-403

\section{2:59:47 pm}

Prepared By:

TWRS System Engineering 
TABLE 1 DOE Relationships

\begin{tabular}{|c|c|c|c|}
\hline ELEMENT TYPE* & INSTANCES & RELATIONSHIP NAME & RELATIONSHIPS \\
\hline \multirow[t]{15}{*}{ SystemRequirement } & \multirow[t]{15}{*}{1460} & annotated by & Comment 1 \\
\hline & & categorized by & Category 1487 \\
\hline & & documented by & Source 1020 \\
\hline & & incorporated by & SystemRequirement 46 \\
\hline & & incorporates & SystemRequirement 46 \\
\hline & & primary is & Organization 141 \\
\hline & & \multirow[t]{2}{*}{ traced from } & Criticallssue 408 \\
\hline & & & Decision 281 \\
\hline & & \multirow[t]{7}{*}{ traces to } & Component 1028 \\
\hline & & & Criticallssue 1 \\
\hline & & & Decision 334 \\
\hline & & & RequiredAnalysis 1 \\
\hline & & & Source 5 \\
\hline & & & TimeFunction 3572 \\
\hline & & & Timeltem 2355 \\
\hline \multirow[t]{10}{*}{ TimeItem } & \multirow[t]{10}{*}{948} & annotated by & Comment 64 \\
\hline & & carried by & ItemLink 50 \\
\hline & & current deconnposition & INet 182 \\
\hline & & input to & TimeFunction 917 \\
\hline & & output from & TimeFunction 963 \\
\hline & & primary is & Organization 150 \\
\hline & & refined by & INet 183 \\
\hline & & \multirow[t]{3}{*}{ traced from } & Criticallssue 99 \\
\hline & & & Decision 1 \\
\hline & & & SysternRequirement 2355 \\
\hline
\end{tabular}


TABLE 1 DOE Relationships

\begin{tabular}{|c|c|c|c|}
\hline ELEMENT TYPE* & INSTANCES & RELATIONSHIP NAME & RELATIONSHIPS \\
\hline \multirow[t]{10}{*}{ Decision } & \multirow[t]{10}{*}{417} & analyzed by & RequiredAnalysis 53 \\
\hline & & categorized by & Category 42 \\
\hline & & documented by & Source 151 \\
\hline & & primary is & Organization 55 \\
\hline & & \multirow[t]{2}{*}{ traced from } & Criticallssue 2 \\
\hline & & & SystemRequirement 334 \\
\hline & & \multirow[t]{4}{*}{ traces to } & Component 132 \\
\hline & & & Criticallssue 91 \\
\hline & & & SystemRequirement 281 \\
\hline & & & TimeItem 1 \\
\hline \multirow[t]{6}{*}{ Source } & \multirow[t]{6}{*}{388} & annotated by & Comment 213 \\
\hline & & categorized by & Category 1 \\
\hline & & \multirow[t]{3}{*}{ documents } & Decision 151 \\
\hline & & & RequiredAnalysis 6 \\
\hline & & & SystemRequirement $\quad 1020$ \\
\hline & & traced from & SystemRequirement 5 \\
\hline \multirow[t]{10}{*}{ Criticallssue } & \multirow[t]{10}{*}{341} & analyzed by & RequiredAnalysis 275 \\
\hline & & primary is & Organization 95 \\
\hline & & secondary is & Organization 1 \\
\hline & & \multirow[t]{3}{*}{ traced from } & Criticallssue 1 \\
\hline & & & Decision 91 \\
\hline & & & SystemRequirement 1 \\
\hline & & \multirow[t]{4}{*}{ traces to } & Component 2 \\
\hline & & & Criticallssue 1 \\
\hline & & & Decision 2 \\
\hline & & & RequiredAnalysis 3 \\
\hline
\end{tabular}


TABLE 1 DOE Relationships

\begin{tabular}{|c|c|c|c|}
\hline \multirow[t]{4}{*}{ ELEMENT TYPE* } & INSTANCES & RELATIONSHIP NAME & RELATIONSHIPS \\
\hline & & & SystemRequirement 408 \\
\hline & & & TimeFunction 7 \\
\hline & & & TimeItem 99 \\
\hline \multirow[t]{7}{*}{ RequiredAnalysis } & \multirow[t]{7}{*}{333} & \multirow[t]{2}{*}{ analyzes } & Criticallssue 275 \\
\hline & & & Decision 53 \\
\hline & & documented by & Source 6 \\
\hline & & primary is & Organization 148 \\
\hline & & secondary is & Organization 6 \\
\hline & & \multirow[t]{2}{*}{ traced from } & Criticallssue 3 \\
\hline & & & SystemRequirement 1 \\
\hline \multirow[t]{5}{*}{ Comment } & \multirow[t]{5}{*}{304} & \multirow[t]{4}{*}{ annotates } & ItemLink 80 \\
\hline & & & Source 213 \\
\hline & & & SystemRequirement 1 \\
\hline & & & TimeItem 64 \\
\hline & & categorized by & Category 4 \\
\hline \multirow[t]{9}{*}{ TimeFunction } & \multirow[t]{9}{*}{190} & current decomposition & FNet 47 \\
\hline & & decomposed by & FNet 48 \\
\hline & & inputs & Timeltem 917 \\
\hline & & outputs & Timeitem 963 \\
\hline & & \multirow[t]{2}{*}{ performed by } & Component 77 \\
\hline & & & System 1 \\
\hline & & primary is & Organization 11 \\
\hline & & \multirow[t]{2}{*}{ traced from } & Criticallssue 7 \\
\hline & & & SystemRequirement $\quad 3572$ \\
\hline \multirow[t]{2}{*}{ Component } & \multirow[t]{2}{*}{80} & built from & Component 79 \\
\hline & & built in & Component 79 \\
\hline
\end{tabular}

* Element Types with no instances are not listed. Element types are sorted by the number of instances. 
TABLE 1 DOE Relationships

\begin{tabular}{|c|c|c|c|}
\hline ELEMENT TYPE* & INSTANCES & RELATIONSHIP NAME & RELATIONSHIPS \\
\hline & & performs & TimeFunction 77 \\
\hline & & \multirow[t]{3}{*}{ traced from } & Criticallssue 2 \\
\hline & & & Decision 132 \\
\hline & & & SystemRequirement 1028 \\
\hline \multirow[t]{2}{*}{ ItemLink } & \multirow[t]{2}{*}{36} & annotated by & Comment 80 \\
\hline & & carries & TimeItem 50 \\
\hline \multirow[t]{8}{*}{ Organization } & \multirow[t]{8}{*}{28} & \multirow[t]{6}{*}{ primary for } & CriticalIssue 95 \\
\hline & & & Decision 55 \\
\hline & & & RequiredAnalysis 148 \\
\hline & & & SystemRequirement 141 \\
\hline & & & TimeFunction 11 \\
\hline & & & TimeItem $\quad 150$ \\
\hline & & \multirow[t]{2}{*}{ secondary for } & CriticalIssue 1 \\
\hline & & & RequiredAnalysis 6 \\
\hline \multirow[t]{4}{*}{ Category } & \multirow[t]{4}{*}{8} & \multirow[t]{4}{*}{ categorizes } & Comment 4 \\
\hline & & & Decision 42 \\
\hline & & & Source 1 \\
\hline & & & SystemRequirement 1487 \\
\hline
\end{tabular}


TABLE 2 DOE Attributes

\begin{tabular}{|c|c|c|c|}
\hline ELEMENT TYPE* & INSTANCES & ATTRIBUTE NAME & ATTRIBUTES \\
\hline \multirow[t]{4}{*}{ SystemRequirement } & \multirow[t]{4}{*}{1460} & Description & 1379 \\
\hline & & Line Number & 1 \\
\hline & & Number & 1149 \\
\hline & & Paragraph Title & 64 \\
\hline \multirow[t]{5}{*}{ TimeItem } & \multirow[t]{5}{*}{948} & Size & 948 \\
\hline & & Description & 923 \\
\hline & & IDEF0 Type & input: 948 \\
\hline & & Number & 61 \\
\hline & & Message Priority & 948 \\
\hline \multirow[t]{7}{*}{ Decision } & \multirow[t]{7}{*}{417} & Alternatives & 74 \\
\hline & & Choice & 113 \\
\hline & & Description & 122 \\
\hline & & Number & 165 \\
\hline & & Problem & 4 \\
\hline & & \multirow[t]{2}{*}{ Status } & Enabling Assumption: 51 \\
\hline & & & Resolved: 113 \\
\hline \multirow[t]{8}{*}{ Source } & \multirow[t]{8}{*}{388} & Abbreviation & 1 \\
\hline & & Description & 286 \\
\hline & & Number & 50 \\
\hline & & \multirow[t]{5}{*}{ Source Type } & Meeting Minutes: 1 \\
\hline & & & $\begin{array}{l}\text { Originating Requirements: } \\
215\end{array}$ \\
\hline & & & Project Memo: 5 \\
\hline & & & Standard: 2 \\
\hline & & & Trade-off Study Report: 5 \\
\hline \multirow[t]{5}{*}{ Criticallssue } & \multirow[t]{5}{*}{341} & Actual Date & 35 \\
\hline & & Description & 338 \\
\hline & & \multirow[t]{2}{*}{ Issue Type } & Issue: 323 \\
\hline & & & Required Analysis: 18 \\
\hline & & Number & 137 \\
\hline
\end{tabular}


TABLE 2 DOE Attributes

\begin{tabular}{|c|c|c|c|}
\hline ELEMENT TYPE* & INSTANCES & ATTRIBUTE NAME & ATTRIBUTES \\
\hline & & Due Date & 114 \\
\hline \multirow[t]{2}{*}{ RequiredAnalysis } & \multirow[t]{2}{*}{333} & Description & 326 \\
\hline & & Number & 138 \\
\hline \multirow[t]{2}{*}{ Comment } & \multirow[t]{2}{*}{304} & Abbreviation & 83 \\
\hline & & Description & 304 \\
\hline \multirow[t]{4}{*}{ TimeFunction } & \multirow[t]{4}{*}{190} & Debugging Mode & none: 190 \\
\hline & & Description & 184 \\
\hline & & Execution Level & follow decomposition: 190 \\
\hline & & Number & 188 \\
\hline \multirow[t]{2}{*}{ Component } & \multirow[t]{2}{*}{80} & Description & 79 \\
\hline & & Number & 80 \\
\hline \multirow[t]{3}{*}{ ItemLink } & \multirow[t]{3}{*}{36} & Abbreviation & 26 \\
\hline & & Is Constrained & false: 36 \\
\hline & & Number & 36 \\
\hline Organization & 28 & & \\
\hline \multirow[t]{2}{*}{ Category } & \multirow[t]{2}{*}{8} & Description & 1 \\
\hline & & Number & 3 \\
\hline
\end{tabular}




\title{
DATABASE PROFILE
}

\author{
of \\ Facility: DOE \\ of the image \\ TWRS-0308.v302
}

10 April 1996

8:09:32 am

Prepared By:

TWRS Systems Engineering

B-16 
TABLE 1 DOE Relationships

\begin{tabular}{|c|c|c|c|}
\hline \multirow[t]{16}{*}{ SystemRequirement } & \multirow[t]{16}{*}{1618} & annotated by & Comment 1 \\
\hline & & categorized by & Category 1609 \\
\hline & & documented by & Source 1035 \\
\hline & & incorporated by & SystemRequirement 46 \\
\hline & & incorporates & SystemRequirement 46 \\
\hline & & primary is & Organization 141 \\
\hline & & traced from & CriticalIssue 410 \\
\hline & & & Decision 280 \\
\hline & & traces to & Component $\quad 1028$ \\
\hline & & & Criticallssue 2 \\
\hline & & & Decision 333 \\
\hline & & & RequiredAnalysis 1 \\
\hline & & & Source 5 \\
\hline & & & TimeFunction 3746 \\
\hline & & & TimeItem 2364 \\
\hline & & & VerificationMethod 453 \\
\hline Timeltem & 958 & annotated by & Comment 64 \\
\hline & & carried by & ItemLink 51 \\
\hline & & current decomposition & INet 183 \\
\hline & & input to & TimeFunction 938 \\
\hline & & output from & TimeFunction 978 \\
\hline & & primary is & Organization 150 \\
\hline & & refined by & INet 184 \\
\hline & & traced from & \begin{tabular}{|l} 
CriticalIssue $\quad 101$ \\
\end{tabular} \\
\hline & & & Decision 1 \\
\hline
\end{tabular}


TABLE 1 DOE Relationships

\begin{tabular}{|c|c|c|c|}
\hline & & & SystemRequirement 2364 \\
\hline \multirow[t]{10}{*}{ Decision } & \multirow[t]{10}{*}{418} & analyzed by & RequiredAnalysis 54 \\
\hline & & categorized by & Category 42 \\
\hline & & documented by & Source 151 \\
\hline & & primary is & Organization 55 \\
\hline & & traced from & Criticallssue 2 \\
\hline & & & SystemRequirement 333 \\
\hline & & traces to & Component 134 \\
\hline & & & Criticallssue 91 \\
\hline & & & SystemRequirement 280 \\
\hline & & & TimeItem 1 \\
\hline \multirow[t]{5}{*}{ Source } & \multirow[t]{5}{*}{393} & annotated by & Comment 213 \\
\hline & & documents & Decision 151 \\
\hline & & & RequiredAnalysis 7 \\
\hline & & & SystemRequirement 1035 \\
\hline & & traced from & SystemRequirement 5 \\
\hline \multirow[t]{9}{*}{ Criticallssue } & \multirow[t]{9}{*}{344} & analyzed by & RequiredAnalysis 276 \\
\hline & & categorized by & Category 1 \\
\hline & & primary is & Organization 95 \\
\hline & & secondary is & Organization 1 \\
\hline & & traced from & Criticallssue 1 \\
\hline & & & Decision 91 \\
\hline & & & SystemRequirement 2 \\
\hline & & traces to & Component 2 \\
\hline & & & CriticalIssue 1 \\
\hline
\end{tabular}

B-18 
TABLE 1 DOE Relationships

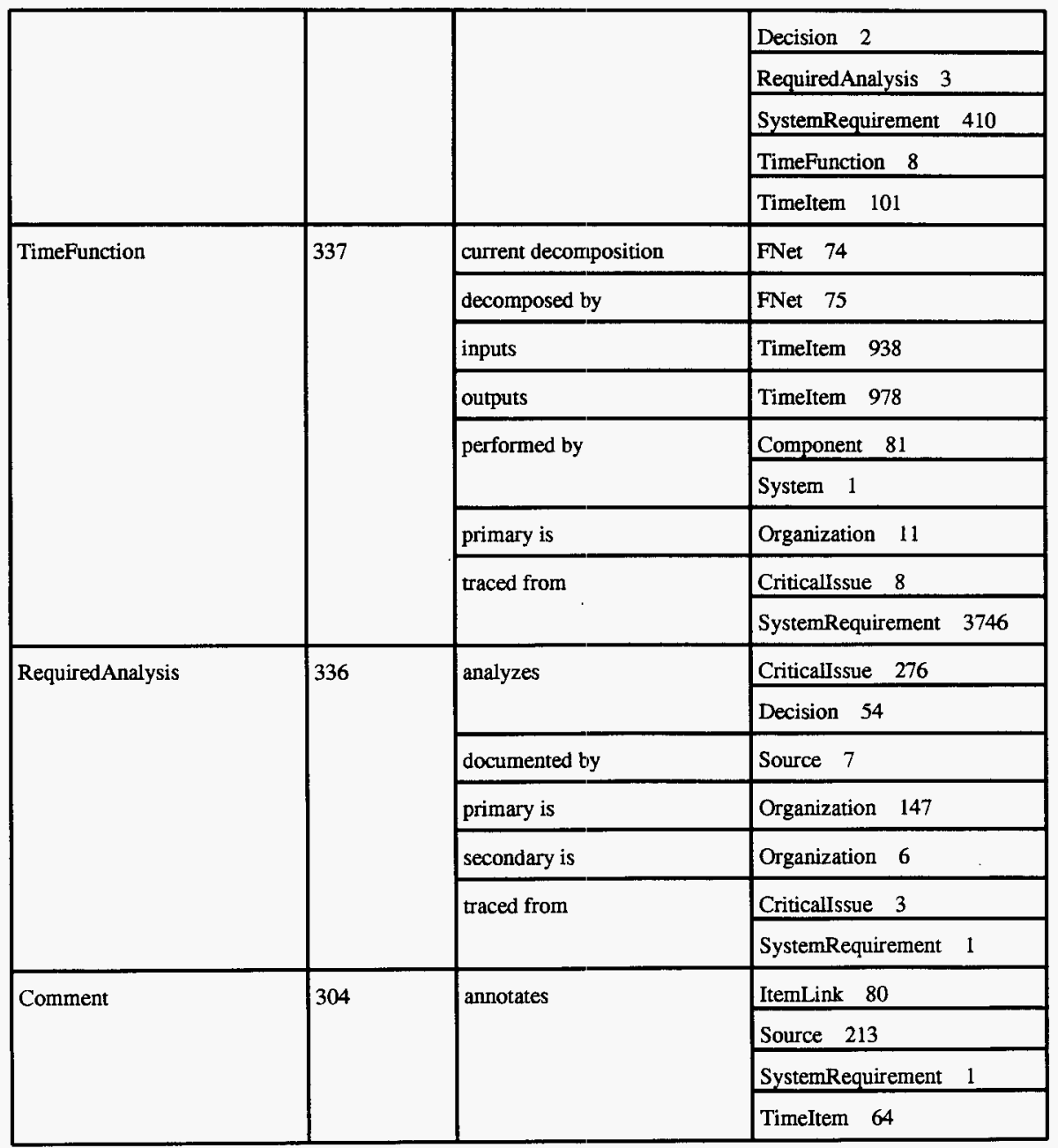

B-19 
TABLE 1 DOE Relationships

\begin{tabular}{|c|c|c|c|}
\hline & & categorized by & Category 4 \\
\hline \multirow[t]{6}{*}{ Component } & \multirow[t]{6}{*}{82} & built from & Component 80 \\
\hline & & built in & Component 80 \\
\hline & & performs & TimeFunction 81 \\
\hline & & \multirow[t]{3}{*}{ traced from } & CriticalIssue 2 \\
\hline & & & Decision 134 \\
\hline & & & SystemRequirement 1028 \\
\hline \multirow[t]{2}{*}{ ItemLink } & \multirow[t]{2}{*}{36} & annotated by & Comment 80 \\
\hline & & carries & TimeItem 51 \\
\hline \multirow[t]{8}{*}{ Organization } & \multirow[t]{8}{*}{28} & \multirow[t]{6}{*}{ primary for } & Criticallssue 95 \\
\hline & & & Decision 55 \\
\hline & & & RequiredAnalysis 147 \\
\hline & & & SystemRequirement 141 \\
\hline & & & TimeFunction 11 \\
\hline & & & TimeItem 150 \\
\hline & & \multirow[t]{2}{*}{ secondary for } & Criticallssue 1 \\
\hline & & & RequiredAnalysis 6 \\
\hline \multirow[t]{4}{*}{ Category } & \multirow{4}{*}{9} & \multirow[t]{4}{*}{ categorizes } & Comment 4 \\
\hline & & & Criticallssue 1 \\
\hline & & & Decision 42 \\
\hline & & & SystemRequirement 1609 \\
\hline VerificationMethod & 5 & traced from & SystemRequirement 453 \\
\hline
\end{tabular}


TABLE 2 DOE Attributes

\begin{tabular}{|c|c|c|c|}
\hline \multirow[t]{4}{*}{ SystemRequirement } & \multirow[t]{4}{*}{1618} & Description & 1539 \\
\hline & & Line Number & 1 \\
\hline & & Number & 1308 \\
\hline & & Paragraph Title & 64 \\
\hline \multirow[t]{5}{*}{ TimeItem } & \multirow[t]{5}{*}{958} & Size & 958 \\
\hline & & Description & 934 \\
\hline & & IDEF0 Type & input: 958 \\
\hline & & Number & 61 \\
\hline & & Message Priority & 958 \\
\hline \multirow[t]{7}{*}{ Decision } & \multirow[t]{7}{*}{418} & Alternatives & 75 \\
\hline & & Choice & 115 \\
\hline & & Description & 122 \\
\hline & & Number & 167 \\
\hline & & Problem & 4 \\
\hline & & \multirow[t]{2}{*}{ Status } & Enabling Assumption: 51 \\
\hline & & & Resolved: 113 \\
\hline \multirow[t]{8}{*}{ Source } & \multirow[t]{8}{*}{393} & Abbreviation & 1 \\
\hline & & Description & 288 \\
\hline & & Number & 51 \\
\hline & & \multirow[t]{5}{*}{ Source Type } & Meeting Minutes: 1 \\
\hline & & & $\begin{array}{l}\text { Originating Requirements: } \\
215\end{array}$ \\
\hline & & & Project Memo: 5 \\
\hline & & & Standard: 2 \\
\hline & & & Trade-off Study Report: 5 \\
\hline \multirow[t]{3}{*}{ Criticallssue } & \multirow[t]{3}{*}{344} & Actual Date & 35 \\
\hline & & Description & 341 \\
\hline & & Issue Type & Issue: 303 \\
\hline
\end{tabular}

B-21 
TABLE 2 DOE Attributes

\begin{tabular}{|c|c|c|c|}
\hline & & & Required Analysis: 18 \\
\hline & & Number & 137 \\
\hline & & Due Date & 114 \\
\hline TimeFunction & 337 & Debugging Mode & none: 337 \\
\hline & & Description & 327 \\
\hline & & Execution Level & follow decomposition: 337 \\
\hline & & Number & 335 \\
\hline RequiredAnalysis & 336 & Description & 329 \\
\hline & & Number & 138 \\
\hline Comment & 304 & Abbreviation & 83 \\
\hline & & Description & 304 \\
\hline Component & 82 & Description & 81 \\
\hline & & Number & 82 \\
\hline ItemLink & 36 & Abbreviation & 26 \\
\hline & & Number & 36 \\
\hline Organization & 28 & & \\
\hline Category & 9 & Number & 3 \\
\hline VerificationMethod & 5 & & \\
\hline
\end{tabular}


WHC-SD-WM-TP-431 Rev. 1

\section{DATABASE PROFILE}

$$
\text { of }
$$

Facility: DOE

of the image

TWRS-030896-403

\section{3:18:59 pm}

\section{Prepared By:}

TWRS Systems Engineering 
TABLE 1 DOE Relationships

\begin{tabular}{|c|c|c|c|}
\hline ELEMENT TYPE* & INSTANCES & RELATIONSHIP NAME & RELATIONSHIPS \\
\hline \multirow[t]{16}{*}{ SystemRequirement } & \multirow[t]{16}{*}{1618} & annotated by & Comment 1 \\
\hline & & categorized by & Category 1609 \\
\hline & & documented by & Source 1035 \\
\hline & & incorporated by & SystemRequirement 46 \\
\hline & & incorporates & SystemRequirement 46 \\
\hline & & primary is & Organization 141 \\
\hline & & \multirow[t]{2}{*}{ traced from } & Criticalissue 410 \\
\hline & & & Decision 280 \\
\hline & & \multirow[t]{8}{*}{ traces to } & Component 1028 \\
\hline & & & Criticallssue 2 \\
\hline & & & Decision 333 \\
\hline & & & RequiredAnalysis 1 \\
\hline & & & Source 5 \\
\hline & & & TimeFunction 3746 \\
\hline & & & Timeltem 2364 \\
\hline & & & VerificationMethod 453 \\
\hline \multirow[t]{10}{*}{ Timeltem } & \multirow[t]{10}{*}{958} & annotated by & Comment 64 \\
\hline & & carried by & ItemLink 51 \\
\hline & & current decomposition & INet 183 \\
\hline & & input to & TimeFunction 924 \\
\hline & & output from & TimeFunction 978 \\
\hline & & primary is & Organization 150 \\
\hline & & refined by & INet 184 \\
\hline & & \multirow[t]{3}{*}{ traced from } & Criticallssue 101 \\
\hline & & & Decision 1 \\
\hline & & & SystemRequirement 2364 \\
\hline
\end{tabular}


TABLE 1 DOE Relationships

\begin{tabular}{|c|c|c|c|}
\hline ELEMENT TYPE* & INSTANCES & RELATIONSHIP NAME & RELATIONSHIPS \\
\hline \multirow[t]{10}{*}{ Decision } & \multirow[t]{10}{*}{418} & analyzed by & RequiredAnalysis 54 \\
\hline & & categorized by & Category 42 \\
\hline & & documented by & Source 151 \\
\hline & & primary is & Organization 55 \\
\hline & & \multirow[t]{2}{*}{ traced from } & Criticallssue 2 \\
\hline & & & SystemRequirement 333 \\
\hline & & \multirow[t]{4}{*}{ traces to } & Component 134 \\
\hline & & & Criticallssue 91 \\
\hline & & & SystemRequirement 280 \\
\hline & & & TimeItem 1 \\
\hline \multirow[t]{5}{*}{ Source } & \multirow[t]{5}{*}{393} & annotated by & Comment 213 \\
\hline & & \multirow[t]{3}{*}{ documents } & Decision 151 \\
\hline & & & RequiredAnalysis 7 \\
\hline & & & SystemRequirement 1035 \\
\hline & & traced from & SystemRequirement 5 \\
\hline \multirow[t]{11}{*}{ Criticalissue } & \multirow[t]{11}{*}{344} & analyzed by & RequiredAnalysis 276 \\
\hline & & categorized by & Category 1 \\
\hline & & primary is & Organization 95 \\
\hline & & secondary is & Organization 1 \\
\hline & & \multirow[t]{3}{*}{ traced from } & CriticalIssue 1 \\
\hline & & & Decision 91 \\
\hline & & & SystemRequirement 2 \\
\hline & & \multirow[t]{4}{*}{ traces to } & Component 2 \\
\hline & & & CriticalIssue 1 \\
\hline & & & Decision 2 \\
\hline & & & RequiredAnalysis 3 \\
\hline
\end{tabular}


TABLE 1 DOE Relationships

\begin{tabular}{|c|c|c|c|}
\hline \multirow[t]{4}{*}{ ELEMENT TYPE* } & \multirow[t]{4}{*}{ INSTANCES } & \multirow{4}{*}{ RELATIONSHIP NAME } & RELATIONSHIPS \\
\hline & & & SystemRequirement $\mathbf{4 1 0}$ \\
\hline & & & TimeFunction 8 \\
\hline & & & TimeItem 101 \\
\hline \multirow[t]{7}{*}{ RequiredAnalysis } & \multirow[t]{7}{*}{336} & \multirow[t]{2}{*}{ analyzes } & Criticallssue 276 \\
\hline & & & Decision 54 \\
\hline & & documented by & Source 7 \\
\hline & & primary is & Organization 147 \\
\hline & & secondary is & Organization 6 \\
\hline & & \multirow[t]{2}{*}{ traced from } & Criticallssue 3 \\
\hline & & & SystemRequirement 1 \\
\hline \multirow[t]{9}{*}{ TimeFunction } & \multirow[t]{9}{*}{330} & current decomposition & FNet 76 \\
\hline & & decomposed by & FNet 77 \\
\hline & & inputs & TimeItem 924 \\
\hline & & outputs & Timeltem 978 \\
\hline & & \multirow[t]{2}{*}{ performed by } & Component 81 \\
\hline & & & System 1 \\
\hline & & primary is & Organization 11 \\
\hline & & \multirow[t]{2}{*}{ traced from } & Criticallssue 8 \\
\hline & & & SystemRequirement 3746 \\
\hline \multirow[t]{5}{*}{ Comment } & \multirow[t]{5}{*}{304} & \multirow[t]{4}{*}{ annotates } & ItemLink 80 \\
\hline & & & Source 213 \\
\hline & & & SystemRequirement 1 \\
\hline & & & Timeltem 64 \\
\hline & & categorized by & Category 4 \\
\hline \multirow[t]{2}{*}{ Component } & \multirow[t]{2}{*}{82} & built from & Component 80 \\
\hline & & built in & Component 80 \\
\hline
\end{tabular}

* Element Types with no instances are not listed. Element types are sorted by the number of instances. 
TABLE 1 DOE Relationships

\begin{tabular}{|c|c|c|c|}
\hline ELEMENT TYPE* & INSTANCES & RELATIONSHIP NAME & RELATIONSHIPS \\
\hline & & performs & TimeFunction 81 \\
\hline & & \multirow[t]{3}{*}{ traced from } & Criticallssue 2 \\
\hline & & & Decision 134 \\
\hline & & & SystemRequirement 1028 \\
\hline \multirow[t]{2}{*}{ ItemLink } & \multirow[t]{2}{*}{36} & annotated by & Comment 80 \\
\hline & & carries & Timeltem 51 \\
\hline \multirow[t]{8}{*}{ Organization } & \multirow[t]{8}{*}{28} & \multirow[t]{6}{*}{ primary for } & Criticallssue 95 \\
\hline & & & Decision 55 \\
\hline & & & RequiredAnalysis $\quad 147$ \\
\hline & & & SystemRequirement 141 \\
\hline & & & TimeFunction 11 \\
\hline & & & TimeItem 150 \\
\hline & & \multirow[t]{2}{*}{ secondary for } & Criticallssue 1 \\
\hline & & & RequiredAnalysis 6 \\
\hline \multirow[t]{4}{*}{ Category } & \multirow[t]{4}{*}{9} & \multirow[t]{4}{*}{ categorizes } & Comment 4 \\
\hline & & & Criticallssue 1 \\
\hline & & & Decision 42 \\
\hline & & & SystemRequirement 1609 \\
\hline VerificationMethod & 5 & traced from & SystemRequirement 453 \\
\hline
\end{tabular}


TABLE 2 DOE Attributes

\begin{tabular}{|c|c|c|c|}
\hline ELEMENT TYPE* & INSTANCES & ATTRIBUTE NAME & ATTRIBUTES \\
\hline \multirow[t]{4}{*}{ SystemRequirement } & \multirow[t]{4}{*}{1618} & Description & 1539 \\
\hline & & Line Number & 1 \\
\hline & & Number & 1308 \\
\hline & & Paragraph Title & 64 \\
\hline \multirow[t]{5}{*}{ TimeItem } & \multirow[t]{5}{*}{958} & Size & 958 \\
\hline & & Description & 934 \\
\hline & & IDEF0 Type & input: 958 \\
\hline & & Number & 61 \\
\hline & & Message Priority & 958 \\
\hline \multirow[t]{7}{*}{ Decision } & \multirow[t]{7}{*}{418} & Alternatives & 75 \\
\hline & & Choice & 115 \\
\hline & & Description & 122 \\
\hline & & Number & 167 \\
\hline & & Problem & 4 \\
\hline & & \multirow[t]{2}{*}{ Status } & Enabling Assumption: 51 \\
\hline & & & Resolved: 113 \\
\hline \multirow[t]{8}{*}{ Source } & \multirow[t]{8}{*}{393} & Abbreviation & 1 \\
\hline & & Description & 288 \\
\hline & & Number & 51 \\
\hline & & \multirow[t]{5}{*}{ Source Type } & Meeting Minutes: 1 \\
\hline & & & $\begin{array}{l}\text { Originating Requirements: } \\
215\end{array}$ \\
\hline & & & Project Memo: 5 \\
\hline & & & Standard: 2 \\
\hline & & & Trade-off Study Report: 5 \\
\hline \multirow[t]{5}{*}{ Criticallssue } & \multirow[t]{5}{*}{344} & Actual Date & 35 \\
\hline & & Description & 341 \\
\hline & & \multirow[t]{2}{*}{ Issue Type } & Issue: 326 \\
\hline & & & Required Analysis: 18 \\
\hline & & Number & 137 \\
\hline
\end{tabular}


TABLE 2 DOE Attributes

\begin{tabular}{|c|c|c|c|}
\hline ELEMENT TYPE* & INSTANCES & ATTRIBUTE NAME & ATTRIBUTES \\
\hline & & Due Date & 114 \\
\hline \multirow[t]{2}{*}{ RequiredAnalysis } & \multirow[t]{2}{*}{336} & Description & 329 \\
\hline & & Number & 138 \\
\hline \multirow[t]{4}{*}{ TimeFunction } & \multirow[t]{4}{*}{330} & Debugging Mode & none: 330 \\
\hline & & Description & 320 \\
\hline & & Execution Level & follow decomposition: 330 \\
\hline & & Number & 328 \\
\hline \multirow[t]{2}{*}{ Comment } & \multirow[t]{2}{*}{304} & Abbreviation & 83 \\
\hline & & Description & 304 \\
\hline \multirow[t]{2}{*}{ Component } & \multirow[t]{2}{*}{82} & Description & 81 \\
\hline & & Number & 82 \\
\hline \multirow[t]{3}{*}{ ItemLink } & \multirow[t]{3}{*}{36} & Abbreviation & 26 \\
\hline & & Is Constrained & false: 36 \\
\hline & & Number & 36 \\
\hline Organization & 28 & & \\
\hline Category & 9 & Number & 3 \\
\hline VerificationMethod & 5 & & \\
\hline
\end{tabular}




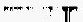

$$
-\pi
$$




\section{APPENDIX C}

\section{Database Content Differences}

The following is the output from the UNIX ${ }^{2}$ diff utility run on two files, each of which contains the name, number and description of every element in the respective databases. It shows that the only differences between the two data sets is in the three places that the degree symbol is used. The degree symbol is evidently accessible in RDD-100 v3.0.2 but not in RDD-100 v4.0.3, and so it shows up as an capital e with a caret over it. Since a method of directly printing the degree symbol in Version 4.0 .3 has not been found, the substitution of the word degrees in place is the symbol is recommended.

\section{$9585 \mathrm{c} 9585$}

$<$ A. Free gas other than air, cover, and radiogenic gases with an immediate internal gas pressure no to exceed $150 \mathrm{kPa}(22 \mathrm{psia})$ at $25^{\circ} \mathrm{C}$. Cover gases shall be helium, argon, or other inert gases. [Derived]

$>$ A. Free gas other than air, cover, and radiogenic gases with an immediate internal gas pressure no to exceed $150 \mathrm{kPa}(22 \mathrm{psia})$ at $25^{\circ} \mathrm{C}$. Cover gases shall be helium, argon, or other inert gases.

[Derived]

$11688 \mathrm{c} 11688$

<Description: At the time of shipment, the producer shall certify that after the initial cool-down, the waste form temperature has not exceeded $400^{\circ} \mathrm{C}$. The producer shall describe the method of compliance in the WCP.

$\cdots$

$>$ Description: At the time of shipment, the producer shall certify that after the initial cool-down, the waste form temperature has not exceeded $400^{\circ} \mathrm{C}$. The producer shall describe the method of compliance in the WCP.

$11741 \mathrm{c} 11741$

< Description: The producer shall ensure that the canistered waste form does not contain detectable amounts of explosive, pyrophoric, or combustible materials. The producer shall describe the method of compliance in the WCP and provide documentation of, the detection limits, and the ability to comply with this specification for the range of waste types, in the WQR. The producer shall document in the WQR that the canistered waste forms remain nonexplosive, nonpyrophoric, and noncombustible after having been subjected to temperatures up to $500^{\circ} \mathrm{C}$.

> Description: The producer shall ensure that the canistered waste form does not contain detectable amounts of explosive, pyrophoric, or combustible materials. The producer shall describe the method of compliance in the WCP and provide documentation of, the detection limits, and the ability to comply with this specification for the range of waste types, in the WQR. The producer shall document in the WQR that the canistered waste forms remain nonexplosive, nonpyrophoric, and noncombustible after having been subjected to temperatures up to $500^{\circ} \mathrm{C}$.

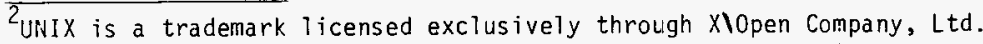

